\title{
Adolescent Cyberbullying in Indonesia: Differentiation between Bullies and Victim
}

\author{
Dina Nazriani, Siti Zahreni
}

Faculty of Psychology

University of Sumatera Utara, Medan, Indonesia

nazriani.dina@usu.ac.id, sitizahreni@gmail.com

\begin{abstract}
Among the negative impact of the widely spread use of the internet is the act of violence in social media, known as cyberbullying. Cyberbullying is when someone repeatedly harasses, mistreats, or makes fun of another person online or while using cell phones or other electronic devices. The adolescence, is one of the most influenced group above all since many of them embraced social networking sites to meet both their personal and relational needs. This study aim to examine the prevalence of bullying in the cyber world among the adolescence. The research method used in this research is quantitative method. While the data for this study were obtained by using a selfreport questionnaire. Samples were selected using multistage cluster random sampling method. We found that the prevalence of cyberbully smaller than cyber victims. The results of this study are expected to provide an accurate picture of the incidence of cyberbullying that henceforth be known means of prevention and treatment of cyberbullying.
\end{abstract}

Keywords: cyberbullying; adolescent

\section{INTRODUCTION}

Cyberbullying is one of the negative impacts on the development of information and communication technology. Research on cyberbullying is getting a lot done in the last ten years. Research on cyberbullying conducted using approaches and diverse sample group. One of the most widely studied is adolescents. This age group is most susceptible involved cyberbullying, either as perpetrators or victims. Adolescence is one of the age groups most affected by the development of information technology. The majority of Internet users in Indonesia are in the age range of $18-25$ years. The number of young users of this age group and almost half (49\%) of the total number of Internet users in Indonesia Reached 88.1 million in 2014 (Maulana, 2015). Since ten years ago, the topic about cyberbullying been often more frequent. Quoted from kompas.com (2016), April 2016 one of a high school student in Medan with the initials SD was admitted as a general daughter after being laid by police. The crew media recorded SD's act during the incident. Furthermore, this incident became much discussed online and SD in the bully on her social media accounts. This case was talking over many people in Indonesia. According to kompas.com (2012) earlier in 2011, a survey institute did a study of parents in 24 countries which was gained 18.687 respondents including Indonesia and found one in ten parents reported that their children had been victims of abuse through online media. Indonesian parents in the sample were aware that cyberbullying was an ongoing phenomenon (91\%), they felt that it required special attention from parents and schools alike (89\%) and they knew of a child in their community who had experienced cyberbullying (53\%). But studies have linked it has not been a lot in Indonesia (Safaria, 2016). Adolescents today are savvy and voracious consumers of electronic media; Thus Spake it should not be surprising that some who wish to tease, harass, or bully others use the electronic media with the which they are so familiar. What may be surprising, though, is the extent to the which cyberbullying Occurs and the effect it has on its victims (Burgess-Proctor, Patchin, \& Hinduja, 2008).

Consider cyberbullying as one focus on research is important Because It Affects the psychological well-being of individuals. With 
regards to the impact on victims of cyber bullying, Patchin and Hinduja (2013) found that victims of bullying and cyber bullying have the wrong adjustment as reactive aggression, instrumental aggression, depression and somatic symptoms. Also, it was found that victims of cyberbullying more at risk for mental health problems and drug abuse, especially trigger suicide attempts. In connection with the perpetrators of cyber bullying (Safaria, 2016) found that the perpetrators of cyber bullying comes from more of a harmonious family..

This study aims to look at the prevalence of cyberbullying among adolescents. In addition, to increasingly understand cyberbullying, we conducted an investigation against cyberbullying regarding the difference between the sexes and the online time that adolescence engaged.

\section{Cyberbullying}

Cyberbullying, defined as willful and repeated harm inflicted through the use of computers, cell phones, and other electronic devices (Hinduja \& Patchin, 2008). According to Hinduja and Patchin (2015) the term cyberbullying refer to the few requirements. First, technology is the main environment where the act is happening. Specifically, the word technology refers to tools that help people to communicate and share the information such as the computer, cell phone, tablet, wifi digital camera, or another electronic device. Second, the frequency that the act is happening must be high, or we could consider is as repeated. The last requirements are must be involved harming others. Cyberbullying can occur through electronic communications media in schools; but in general cyberbullying can happen outside of the school environment (Griezel, Craven, Yeung, \& Finger, 2008).

Cyberbullying involves two groups of perpetrators and victims. There were many ways to express both groups, but we choose to use cyberbullies to represent the perpetrators and cyber victims to represent the victims.. Cyberbully are individuals who deliberately and repeatedly hurt others using technology such as phones or computers. While cyber victim are individuals, who receive repeated harmful behavior while using technology such as phones and computers.

\section{RESEARCH METHODS}

We use a self-report questionnaire to obtain data about cyberbully and cybervictim. The research instrument is called Cyberbullying and Online Aggression Survey Instrument was based on Hinduja and Patchin (2015) research. The instrument was translated to Bahasa Indonesia. The instrument is comprising items of cyberbully (9 items) and cybervictim (9 items). Respondents choose never, once, a few times, several times, many times. Summary scale uses to decide whether the respondents being cyberbully or cybervictim. The cyberbully scale reliability was 0.90 . The cybervictim scale reliability was 0.85. A multistage cluster random sampling is used to choose 232 students from the secondary and high schools located in rural and urban area in Medan.

\section{RESULTS}

\section{A. Prevalence of Cyberbullying}

Table 1 shows there are a number of 78 adolescents who reported theirself as the cyberbully. In proportion means that there are about $36 \%$ of adolescents are cyberbully. Table 1 also shows that some 117 adolescents claimed to have become cybervictims. In a proportion of approximately $50 \%$ of teens are cybervictims. In addition, this study obtained data 68 adolescents claimed to be cyberbully and cybervictims or about 29\%. From Table 1 but can also note that 105 adolescents did not become cyberbully and cybervictims or about $45 \%$. The interesting thing is ten adolescents reported themselves as cyberbully but not cybervictims or about $4 \%$. Furthermore, there are a number of 49 adolescents who reported themselves as not cyberbully but being cybervictims or about $21 \%$. 
TABLE 1. PREVALENCE OF CyBerbullying

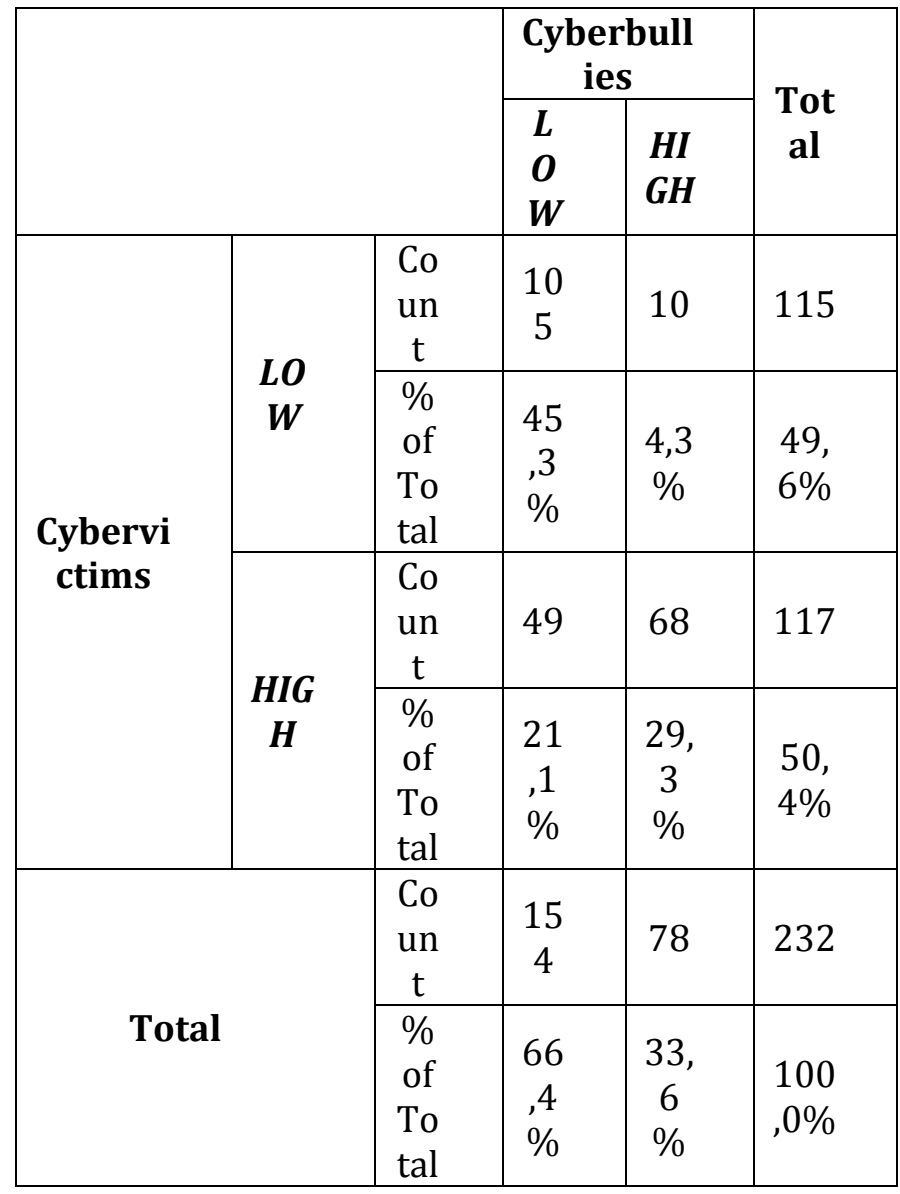

\section{B. Demographic Characteristic}

We have found that based on the category of gender, there were a slightly differences on frequencies of cyberbully and cybervictim. Fig 1. shows 39 male adolescents reports himself as the cyberbully and 41 female adolescents reports herself as the cyberbully. Furthermore, there were 54 male adolescent reports himself as cybervictim and 62 female adolescents report herself as a cybervictims. Based on descriptive statistics we have found that 32 male adolescents once becomes cyberbully and cybervictims. While from female adolescent groups there were 36 adolescents once becomes cyberbully and cybervictims. Using Pearson Chi-square we have found there was a relationship between gender and the tendency to become cybervictims.

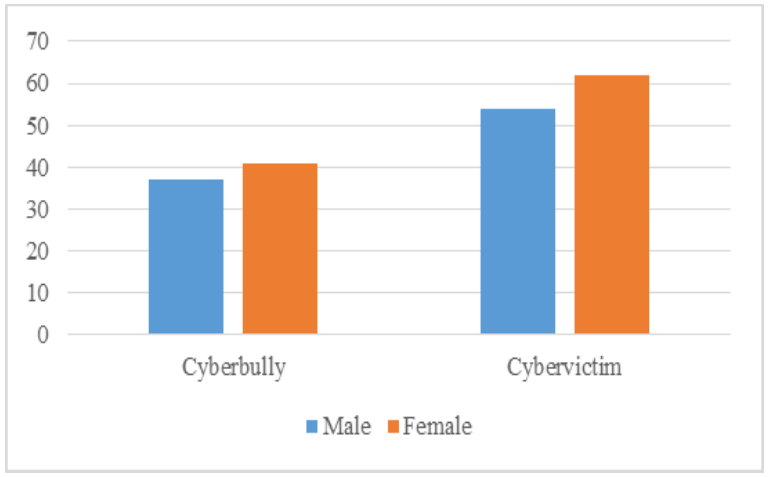

\section{Online Time and Cyberbullying}

The data shows how long did the adolescent spend the time to use the internet per day or we usually called it online time. We know from the data that most of the adolescent spent as much as 1-5 hours per day to use the internet.

Both cyberbully and cybervictim have this characteristic. Using the Pearson Chi-square we found that there was a relationship between the online time and a tendency to become a cyberbully. Meanwhile, from the side of cybervictim, there was no evidence that online time could have the relationship with it.

\section{CONCLUSION}

We have found the vast prevalence of the cyberbullying, specifically on adolescent target group. The results of this study support previous research carried out by Safaria (2016) which found that $80 \%$ of adolescents are involved in cyberbullying. The interesting this was the number of the adolescent who reported themselves as cyber bully and cybervictims. It needs to be studied about the possibility of a cyber bully has once become cybervictims. Cyberbullying is becoming one of the more obvious negative impacts on the development of technology and information. Meanwhile, the data shows some differences come from gender differences regards on cyber bully and cybervictim. Having known that cyberbullying prevalence was vast, we need to takes a joint effort so that the negative impact of information and technology would be minimized. Producing guidelines needed to identify the characteristics of the cyber bully and cybervictim. An understanding of the factors that increase the incidence of cyberbullying requires further research.

\section{ACKNOWLEDGMENT}

We would like to thank the Research Institute at the University of North Sumatra who have supported us in conducting this study through a research grant scheme Keunggulan 
Akademik (TALENTA) USU for the fiscal year 2016.

\section{REFERENCES}

Burgess-Proctor, A., Patchin, J. W., \& Hinduja, S. (2008). Cyberbullying and Onlie Harassment: Reconceptualizing the Victimization of Adolescent Girls (pp. 162176). Author : Florida.

Griezel, L., Craven, R.G., Yeung, A.S., \& Finger, L. R. (2008). The development of a multidimensional measure of cyberbullying. Brisbane: Australian Association for research in Education.

Hinduja, S., \& Patchin, J. W. (2008). Cyberbullying: An Exploratory Analysis of Factors Related to Offending and Victimization. Deviant Behavior, 29(2), 129-156. https://doi.org/10.1080/0163962070145 7816

Hinduja, S. \& Patchin, J. W. (2015). Bullying Beyond the Schoolyard: Preventing and Responding to Cyberbullying (2nd edition). Thousand Oaks, CA: Sage Publications.

Kompas. (2012.). Violence in cyberspace threaten children. Retrieved 20 Juni 2016 from http://edukasi.kompas.com/read/2012/01
/23/18024424/Kekerasan.di.Dunia.Maya. Mengancam.Anak-anak

Kompas.com (2016). Distop Saat Konvoi Usai UN, Siswi SMA Marahi Polisi dan Mengaku Anak Jenderal. Retrieved 20th June 2016 from http://regional.kompas.com/read/2016/0 4/07/09141091/Distop.Saat.Konvoi.Usai.U N.Siswi.SMAMarahi.Polisi.dan.Mengaku.An ak.Jenderal

Maulana, A.;. (2015, Maret 26). Pengguna Internet Indonesia Didominasi Remaja \& Wanita. Retrieved Juni 22, 2016, from www. tekno.liputan6.com:

http://tekno.liputan6.com/read/2197439/ pengguna-internet-indonesia-didominasiremaja-amp-wanita

Patchin, J. W., \& Hinduja, S. (2013). Cyberbullying among adolescents: Implications for empirical research. Journal of Adolescent Health, 53(4), 431-432. https://doi.org/10.1016/j.jadohealth.2013. 07.030

Safaria, T. (2016). Prevalence and impact of cyberbullying in a sample of indonesian junior high school students. Turkish Online Journal of Educational Technology, 15(1), 82-91. 